\title{
Characterization of the Physicochemical and Thermal properties of the Biofield Energy Treated Flutamide Using PSA, PXRD, TGA/DTG, and DSC Analytical Techniques
}

\author{
Alice Branton ${ }^{1}$, Mahendra Kumar Trivedii ${ }^{1}$, Dahryn Trivedi ${ }^{1}$, Gopal Nayak ${ }^{1}$ and Snehasis Jana ${ }^{2 *}$ \\ ${ }^{1}$ Trivedi Global, USA \\ ${ }^{2}$ Trivedi Science Research Laboratory Pvt. Ltd., India
}

Submission: November 01, 2018; Published: January 29, 2019

*Corresponding author: Snehasis Jana, Trivedi Science Research Laboratory Pvt. Ltd., Bhopal, India

\begin{abstract}
Flutamide is an antiandrogen drug that blocks the action of testosterone by binding to the androgen receptor. This study was designed to determine the impact of the Trivedi Effect ${ }^{\circledR}$-Energy of Consciousness Healing Treatment on the physicochemical and thermal properties of flutamide. The test sample was divided into two parts, i.e., control and treated sample. The control part was known as untreated sample, while the treated part remotely received the Biofield Energy Healing Treatment by a renowned Biofield Energy Healer, Alice Branton. The study showed that the particle size values were significantly increased by $15.82 \%\left(\mathrm{~d}_{10}\right), 16.36 \%\left(\mathrm{~d}_{50}\right), 1.05 \%\left(\mathrm{~d}_{90}\right)$, and $5.10 \%\{\mathrm{D}(4,3)\}$; thus, the specific surface area was significantly decreased by $14.56 \%$ in the treated sample compared with the control sample. The PXRD peak intensities and crystallite sizes were significantly altered ranging from $7.02 \%$ to $29.41 \%$ and $-9.17 \%$ to $17.86 \%$, along with $2.84 \%$ increase in the average crystallite size in the treated flutamide compared to the control sample. The residue weight was significantly decreased by $64.16 \%$; however, the maximum thermal degradation temperature was increased by $10.16 \%$ in the treated sample compared to the control sample. The latent heat of the treated sample reduced by $9.37 \%$ compared with the control sample. The results revealed the significant alteration in the crystallinity, particle size and thermal stability of the treated sample as compared to the untreated sample. Thus, the Biofield Energy Treated flutamide might improve the flowability, and compatibility compared with the untreated sample, that may help in designing a better pharmaceutical formulation in terms of its performance against various diseases.
\end{abstract}

Keywords: Flutamide, The Trivedi Effect ${ }^{\circledR}$, Energy of consciousness haling treatment, Complementary and alternative medicine, PSA, PXRD, TGA, DSC

\section{Introduction}

Flutamide is a nonsteroidal pure antiandrogen drug (toluidine derivative, structurally associated to bicalutamide and nilutamide), which perform its action by inhibiting the uptake and/ or binding of dihydrotestosterone to the target cell receptor that leads to alter the interfering with the androgen action. It blocks the action of both endogenous and exogenous testosterone by binding to the androgen receptor, thus flutamide administration results in elevations of plasma testosterone and estradiol [1]. However, it was reported that it is a potent inhibitor of testosterone-stimulated prostatic DNA synthesis. 2-Hydroxyflutamide, an active metabolite of flutamide competitively blocks the dihydrotestosterone binding at androgen receptors, which results in the formation of inactive complexes that could not be translocate into the cell nucleus. This property is significantly useful to arrest the growth of tumour cell or transient tumour regression [2]. Absorption, distribution, and excretion of flutamide is very rapid and absorbed completely. In addition, it is rapidly and extensively metabolized with only $2.5 \%$ of plasma radioactivity of 1 hour after administration. The biological half-life of the alpha-hydroxylated metabolite of flutamide is approximately 6 hours. Flutamide, as an anti-androgens action used to treat prostate cancer in men, by blocking the effects of testosterone that helps prostate cancer to grow and also significantly used with other medications for radiation treatments [3]. Flutamide is administered and preferred orally, while it is $95 \%$ plasma protein-bound and seems to concentrate in the prostate. The data suggested that flutamide undergoes rapid metabolism to a variety of compounds. However, $95 \%$ of an oral dose is excreted by the kidneys. Hemodialysis cannot remove it due to its high protein binding. It might have some side effects because this is commonly used with other medications, such as hot flashes, diarrhoea and nausea, loss of sexual interest/ability, vomiting, and enlargement of male breasts. However, drowsiness is one of 
the less common side effects, while diarrhoea is a common side effect. The rate of absorption and mechanism of action depends upon various factors of drugs such as its solubility, stability, pharmacokinetics and bioavailability $[4,5]$. However, physicochemical properties of any pharmaceuticals are very important in the different role for its biological profile. Therefore, in order to improve the physiochemical profile such as such as particle size, crystalline structure, crystallite size, surface area, etc., research has been carried to alter the physicochemical properties.

The Biofield Energy Treatment is considered as an emerging field as it is an integral healthcare approach including the increasing beneficial effects of Complementary and Alternative Medicine (CAM) therapies, against various health conditions $[6,7]$. National Institute of Health (NIH) recommend and included various Energy Healing therapies such as natural products, yoga, deep breathing, meditation, homeopathy, progressive relaxation, acupressure, acupuncture, hypnotherapy, relaxation techniques, healing touch, pilates, Ayurvedic medicine, traditional Chinese herbs and medicines, Reiki, cranial sacral therapy, etc. under CAM category and these are accepted by most of the U.S. population with several advantages [8,9]. Similarly, the Biofield Energy Healing (the Trivedi Effect ${ }^{\circledR}$ ) has also been popular worldwide due to its remarkable impact on the nonliving materials as well as the living organisms. The Trivedi Effect $^{\circledR}$-Consciousness Energy Healing Treatment has been reported for its significant impact on the physicochemical and thermal properties of various pharmaceutical/nutraceutical compounds [10-12], plants [13,14], altered characteristics in microbiology [15-17], metals, ceramics, and polymers [18,19], livestock [20], biotechnology [21], and skin health [22]. Thus, this study was aimed to determine the effect of the Biofield Energy Treatment (Trivedi Effect ${ }^{\circledR}$ ) on the physicochemical and thermal properties of flutamide by using various analytical techniques such as, particle size analysis (PSA), powder X-ray diffraction (PXRD), thermogravimetric analysis (TGA), and differential scanning calorimetry (DSC).

\section{Materials and Methods}

\section{Chemicals and reagents}

Flutamide was purchased from Tokyo Chemical Industry Co. Ltd. All other chemicals used during the experiments were of analytical grade available in India.

\section{Consciousness energy healing treatment strategies}

Flutamide, i.e., the test compound was divided into two parts. Among both parts, one portion was denoted as control sample that did not receive the Biofield Energy Treatment. Besides, the other part of flutamide was considered as the treated part that received the Energy of Consciousness Healing Treatment by the renowned Biofield Energy Healer, Alice Branton (USA), and named as the Biofield Energy Treated sample. In the process of Biofield Energy Treatment, the sample was kept under the standard laboratory conditions, and the Biofield Energy Healer provided the Trivedi Effect ${ }^{\circledR}$ - Energy of Consciousness Healing Treatment to the sample, remotely, for 3 minutes through the Unique Energy
Transmission process. On the other hand, the control flutamide was subjected to a "sham" healer under the similar laboratory conditions, who did not have any knowledge about the Biofield Energy Healing Treatment. Consequently, the control as well as Biofield Energy Treated flutamide samples were kept in similar sealed conditions and further characterized by using modern analytical techniques.

\section{Characterization}

The PSA, PXRD, TGA/DTG, and DSC analysis of pyridoxine were performed. The PSA was performed using Malvern Mastersizer 2000, from the UK with a detection range between $0.01 \mu \mathrm{m}$ to $3000 \mu \mathrm{m}$ using the wet method $[23,24]$. The PXRD analysis of pyridoxine powder sample was performed with the help of Rigaku MiniFlex-II Desktop X-ray diffractometer (Japan) $[25,26]$. The average size of crystallites was calculated from PXRD data using the Scherrer's formula (1)

$$
G=\frac{K \lambda}{\beta \cos \theta}
$$

Where $\mathrm{G}$ is the crystallite size in $\mathrm{nm}, \mathrm{k}$ is the equipment constant (0.94), $\lambda$ is the radiation wavelength $(0.154056 \mathrm{~nm}$ for $\mathrm{K} \alpha$ 1 emission), $\beta$ is the full-width at half maximum, and $\theta$ is the Bragg angle [27]. Similarly, The TGA/DTG thermograms of pyridoxine were obtained with the help of TGA Q50 TA instruments. The DSC analysis of pyridoxine was performed with the help of DSC Q200, TA instruments $[23,24]$. The \% change in particle size, specific surface area (SSA), peak intensity, crystallite size, melting point, latent heat, weight loss and the maximum thermal degradation temperature $\left(\mathrm{T}_{\max }\right)$ of the Biofield Energy Treated sample was calculated compared with the control sample using the following equation 2:

$$
\% \text { Change in weight loss }=\frac{[\text { Treated- Control }]}{\text { Control }} * 100 \ldots . .
$$

\section{Results and Discussion}

\section{Particle size analysis (PSA)}

The particle size analysis of the control and Biofield Energy Treated samples were presented in Table 1. The particle size distribution of the control sample was found at $d_{10}=44.31 \mu \mathrm{m}, \mathrm{d}_{50}$ $=179.98 \mu \mathrm{m}, \mathrm{d}_{90}=653.57 \mu \mathrm{m}$, and $\mathrm{D}(4,3)=276.60 \mu \mathrm{m}$. However, the particle size distribution of the Biofield Energy Treated flutamide sample was observed at $d_{10}=51.32 \mu \mathrm{m}, \mathrm{d}_{50}=209.43 \mu \mathrm{m}$, $\mathrm{d}_{90}=660.45 \mu \mathrm{m}$, and D $(4,3)=290.70 \mu \mathrm{m}$. The result analysis revealed that the particle size values at $d_{10}, d_{50}, d_{90}$, and $D(4,3)$ in the Biofield Energy Treated sample were significantly increased by $15.82 \%, 16.36 \%, 1.05 \%$, and $5.10 \%$, respectively, compared to the control sample.

On the other hand, the specific surface area of the Biofield Energy Treated flutamide $\left(0.088 \mathrm{~m}^{2} / \mathrm{Kg}\right)$ was decreased by $14.56 \%$ as compared with the control sample $\left(0.103 \mathrm{~m}^{2} / \mathrm{Kg}\right)$. The literature reported the impact of particle size distribution of drug on 
the formulation development in terms of its blend uniformity, compactibility, and flowability, etc., which further affected the safety, efficacy, and the quality of the formulation [28,29]. Hence,

the Biofield Energy Treated flutamide sample might help in better formulation development by improving its uniformity, flowability, and compactibility.

Table 1: Particle size distribution of the control and Biofield Energy Treated flutamide.

\begin{tabular}{|c|c|c|c|c|c|}
\hline Parameter & $\mathbf{d}_{\mathbf{1 0}}(\boldsymbol{\mu m})$ & $\mathbf{d}_{\mathbf{5 0}}(\boldsymbol{\mu m})$ & $\mathbf{d}_{\mathbf{9 0}}(\boldsymbol{\mu m})$ & $\mathbf{D}(\mathbf{4 , 3})(\boldsymbol{\mu m})$ & $\mathbf{S S A}\left(\mathbf{m}^{2} \mathbf{g}\right)$ \\
\hline Control & 44.31 & 179.98 & 653.57 & 276.6 & 0.103 \\
\hline Biofield Treated & 51.32 & 209.43 & 660.45 & 290.7 & 0.088 \\
\hline Percent change* $(\%)$ & 15.82 & 16.36 & 1.05 & 5.1 & -14.56 \\
\hline
\end{tabular}

$d_{10}, d_{50}$, and $d_{90}$ : particle diameter corresponding to $10 \%, 50 \%$, and $90 \%$ of the cumulative distribution, $D(4,3)$ : the average mass-volume diameter, and SSA: the specific surface area. ${ }^{*}$ denotes the percentage change in the Particle size distribution of the Biofield Energy Treated sample with respect to the control sample.

\section{Powder X-ray Diffraction (PXRD) Analysis}

Table 2: PXRD data for the control and Biofield Energy Treated flutamide.

\begin{tabular}{|c|c|c|c|c|c|c|c|c|}
\hline \multirow{2}{*}{ Entry No. } & \multicolumn{2}{|c|}{ Bragg angle $\left({ }^{\circ} 2 \theta\right)$} & \multicolumn{3}{|c|}{ Intensity (cps) } & \multirow{2}{*}{$\begin{array}{c}\text { Crystallite size }(\mathrm{G}, \mathrm{nm}) \\
\text { Control }\end{array}$} & \multirow[b]{2}{*}{ Treated } & \multirow[b]{2}{*}{$\%$ change $^{b}$} \\
\hline & Control & Treated & Control & Treated & $\%$ change $^{a}$ & & & \\
\hline 1 & 8.85 & 8.72 & 3489 & 3734 & 7.02 & 162.9 & 192 & 17.86 \\
\hline 2 & 17.42 & 17.37 & 597 & 751 & 25.8 & 154 & 167 & 8.44 \\
\hline 3 & 18.97 & 18.94 & 1735 & 2003 & 15.45 & 162 & 154 & -4.94 \\
\hline 4 & 26.21 & 26.11 & 1439 & 1589 & 10.42 & 122.7 & 126 & 2.69 \\
\hline 5 & 40.47 & 40.31 & 629 & 814 & 29.41 & 169 & 153.5 & -9.17 \\
\hline
\end{tabular}

a: Denotes the percentage change in the peak intensity of Biofield Energy Treated sample with respect to the control sample.

b: Denotes the percentage change in the crystallite size of Biofield Energy Treated sample with respect to the control sample.
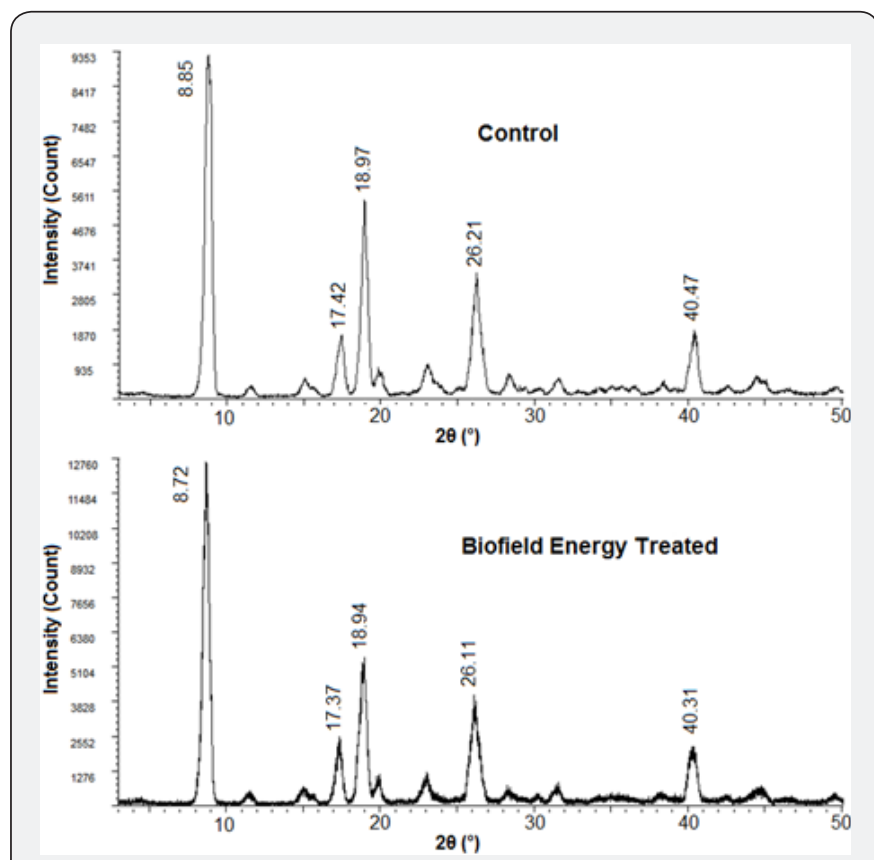

Figure 1: PXRD diffractograms of the control and Biofield Energy Treated flutamide.

The PXRD diffractograms of the control and Biofield Energy Treated flutamide samples are shown in Figure 1. There was the presence of sharp and intense peaks in the diffractograms of both the samples which indicated that both the samples are crystalline in nature. Besides, the peak intensities and the crystallite size corresponding to each characteristic peak was done for both the control and the Biofield Energy Treated sample (Table 2).
The highest peak intensity (100\%) was observed at $2 \theta$ equal to $8.85^{\circ}$ (Table 2, entry 1 ) in the PXRD diffractogram of the control sample, while at $8.72^{\circ}$ in the Biofield Energy Treated sample; however, the Bragg's angle of all the characteristic peaks of the Biofield Energy Treated sample were observed to differ from the control sample. Also, the peak intensities corresponding to these characteristic diffraction peaks in the Biofield Energy Treated sample were found to be significantly increased ranging from $7.02 \%$ to $29.41 \%$ compared to the control sample. Such alterations in the peak intensities of the peaks indicated the change in the crystallinity of the Biofield Energy Treated sample as compared to the control flutamide sample.

Besides, the crystallite sizes of the Biofield Energy Treated sample corresponding to those peaks were also observed to be significantly altered ranging from $-9.17 \%$ to $17.86 \%$ as compared to the control sample. Also, the Biofield Energy Treated sample showed an increase in the average crystallite size $(158.5 \mathrm{~nm})$ by $2.84 \%$ as compared to the control sample $(154.12 \mathrm{~nm})$. The literature reported that the alterations in the peak intensity of the crystalline compound changes based on its crystal morphology [30]. Moreover, the alterations in the complete PXRD pattern may be considered as the proof of polymorphic transitions taken place in treated flutamide sample [31,32]. Thus, the overall results indicated the alterations in the crystallinity, crystallite size, and polymorphic form of the Biofield Energy Treated flutamide sample when compared with the control sample. Such changes might ensure its better drug performance in the formulation development than the untreated flutamide. 
Thermal gravimetric analysis (TGA)/ Differential thermogravimetric analysis (DTG)

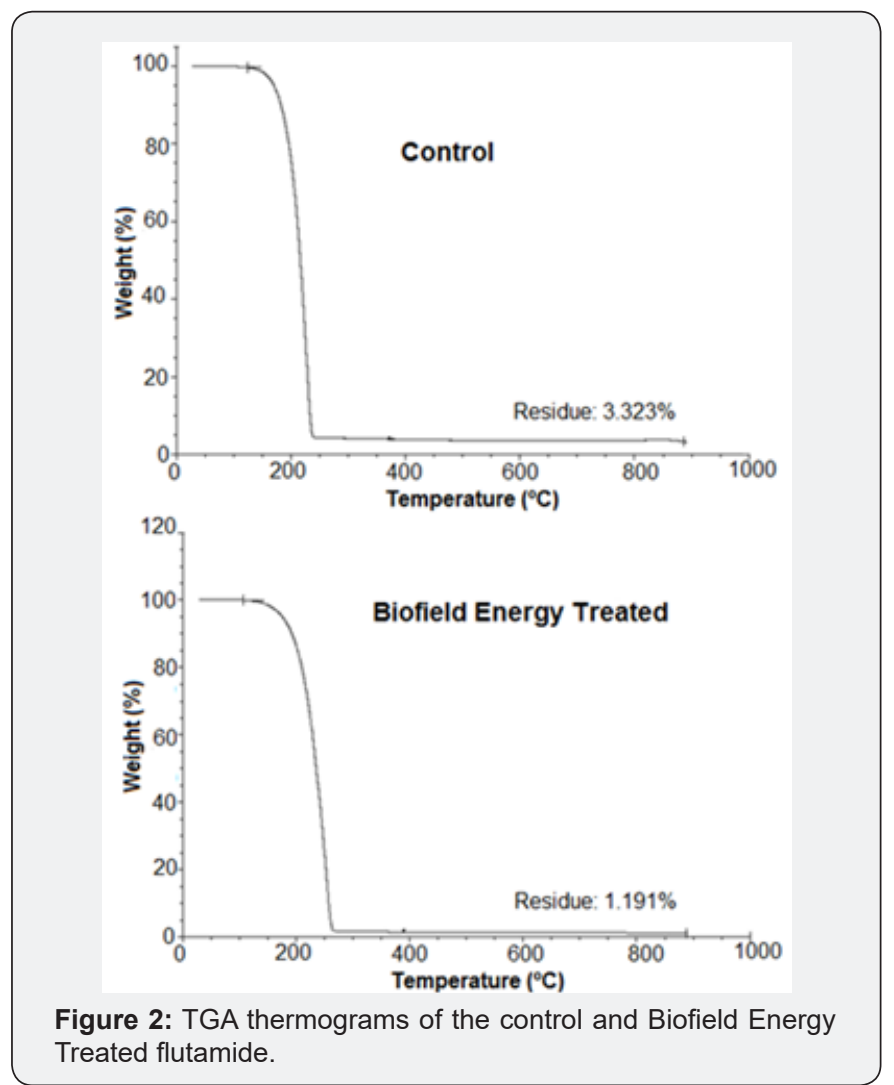

The TGA thermograms of the control and Biofield Energy Treated flutamide samples displayed one step of thermal degradation (Figure 2). The results revealed $2.21 \%$ increase in the total weight loss of the Biofield Energy Treated flutamide as compared with the control sample (Table 3). Also, the residue amount of the treated flutamide sample was reduced significantly by $64.16 \%$ when compared to the control sample (Table 3).

Table 3: TGA/DTG data of the control and Biofield Energy Treated samples of flutamide.

\begin{tabular}{|c|c|c|c|}
\hline \multirow{2}{*}{ Sample } & TGA & \multicolumn{2}{|c|}{ DTG } \\
\cline { 2 - 4 } & Total weight loss (\%) & Residue \% & $\mathbf{T}_{\max }{ }^{\circ} \mathbf{C}$ ) \\
\hline Control & 96.677 & 3.323 & 227.25 \\
\hline $\begin{array}{c}\text { Biofield Energy } \\
\text { Treated }\end{array}$ & 98.809 & 1.191 & 250.35 \\
\hline \% Change* & 2.21 & -64.16 & 10.16 \\
\hline
\end{tabular}

*denotes the percentage change of the Biofield Energy Treated sample with respect to the control sample,

$\mathrm{T}_{\max }=$ the temperature at which maximum weight loss takes place in $\mathrm{TG}$ or peak temperature in DTG.

The DTG thermograms of the control and Biofield Energy Treated sample showed a single peak (Figure 3). The results revealed that the onset of thermal degradation taken place at $134.68^{\circ} \mathrm{C}$ in the control flutamide sample, while it started earlier in the Biofield Energy Treated sample i.e., at $103.41^{\circ} \mathrm{C}$. However, the maximum thermal degradation temperature $\left(\mathrm{T}_{\max }\right)$ of the treated flutamide sample was significantly increased by $10.16 \%$ as compared with the control sample (Table 3). Thus, the overall, TGA/DTG results showed that the thermal stability of the Biofield Energy Treated sample was significantly decreased as compared with the control flutamide sample.

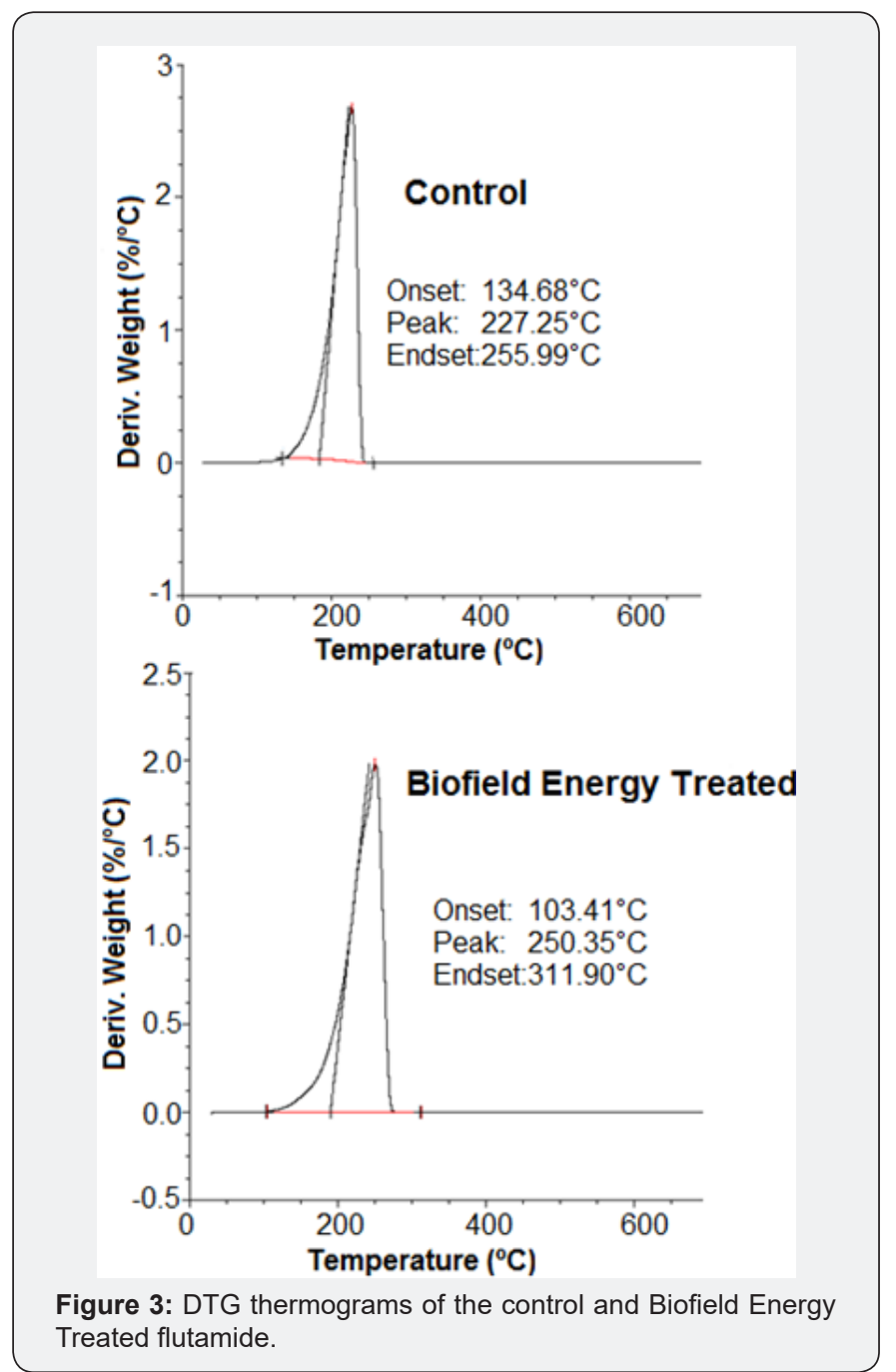

\section{Differential scanning calorimetry (DSC) analysis}

Table 4: DSC data for the control and Biofield Energy Treated samples of flutamide.

\begin{tabular}{|c|c|c|}
\hline Sample & Melting point $\left({ }^{\circ} \mathbf{C}\right)$ & $\mathbf{\Delta H}(\mathbf{J} / \mathbf{g})$ \\
\hline Control Sample & 113.23 & 107.2 \\
\hline Biofield Energy Treated & 112.58 & 97.15 \\
\hline \% Change* & -0.57 & -9.37 \\
\hline
\end{tabular}

$\Delta \mathrm{H}$ : Latent heat of fusion, ${ }^{*}$ denotes the percentage change of the Biofield Energy Treated sample with respect to the control sample.

The DSC thermograms of both the control and the Biofield Energy Treated flutamide samples were shown in Figure 4 and the results were used to determine the melting and other thermal behaviours of the flutamide sample [33]. A sharp endothermic peak was evident in the thermograms of both the samples which are considered as the melting temperature of the samples. The peak was observed in the control sample at $113.23^{\circ} \mathrm{C}$; while it was slightly decreased to $112.58^{\circ} \mathrm{C}$ in the Biofield Energy Treated flutamide sample. Moreover, the latent heat of fusion $(\Delta \mathrm{H})$ of the con- 
trol sample was found as $107.2 \mathrm{~J} / \mathrm{g}$; whereas it was decreased to 97.15J/g in the Biofield Energy Treated sample. Hence, the results revealed a reduction in the melting point and the $\Delta \mathrm{H}_{\text {fusion }}$ of the Biofield Energy Treated flutamide by $0.57 \%$ and $9.37 \%$, respectively as compared to the control sample (Table 4). It is presumed that there was might be some alterations in the molecular chains and the crystallization structure of the flutamide [33] due to the Biofield Energy Treatment that may cause the changes in the melting temperature and $\Delta \mathrm{H}$ of the treated flutamide.

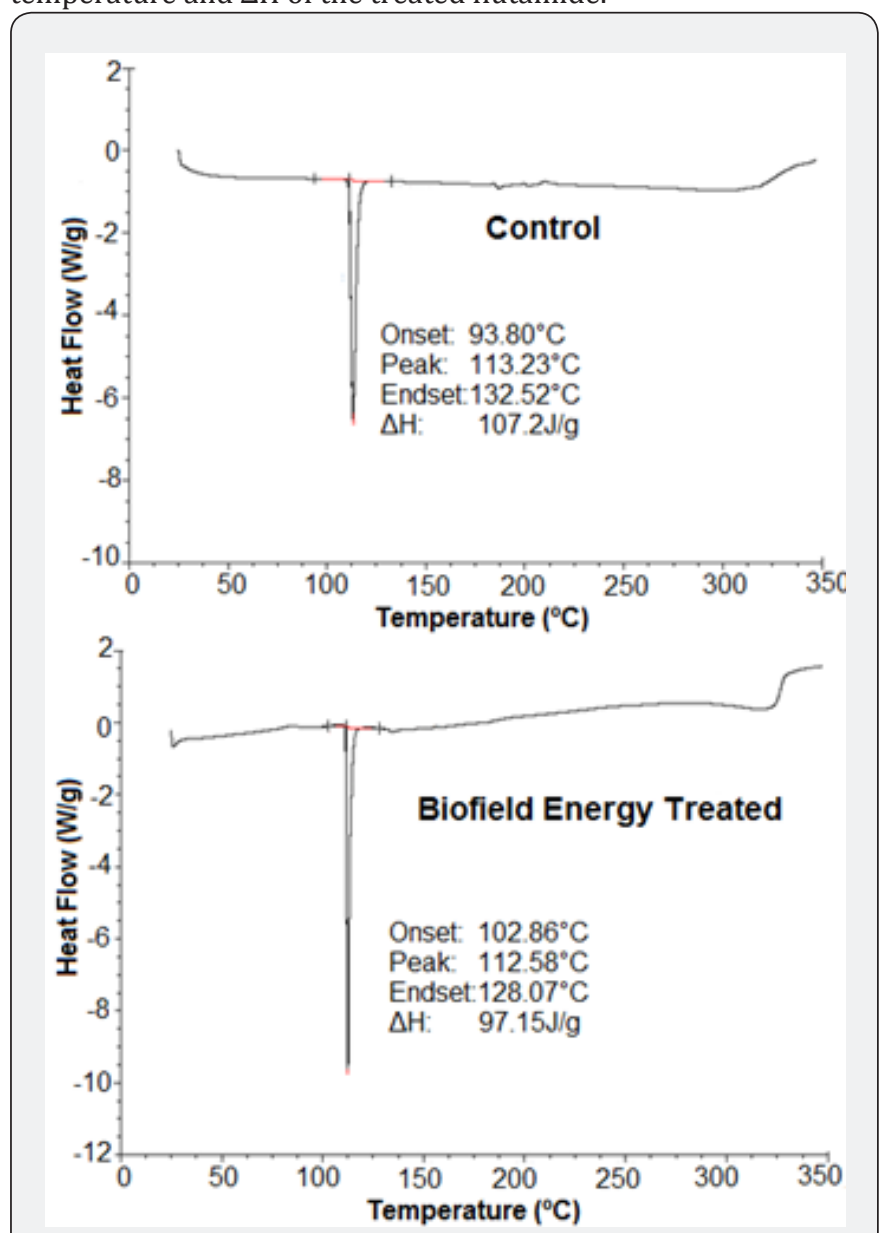

Figure 4: DSC thermograms of the control and Biofield Energy Treated flutamide.

\section{Conclusion}

The study revealed that the Trivedi Effect ${ }^{\circledR}$-Consciousness Energy Healing Treatment showed a significant impact on the particle size distribution, crystallite sizes, peak intensities, and the thermal properties of flutamide. The particle size values of the Alice's Biofield Energy Treated flutamide were increased significantly by $15.82 \%, 16.36 \%, 1.05 \%$, and $5.10 \%$ at $\mathrm{d}_{10}, \mathrm{~d}_{50}$, $\mathrm{d}_{90}$, and $\mathrm{D}(4,3)$, respectively compared to the control sample. The specific surface area of the Biofield Energy Treated sample was found to be decreased by $14.56 \%$ compared to the untreated flutamide sample. The increase in particle size might be helpful in providing the better compactibility, uniformity, and flowability to the treated flutamide sample. The PXRD results showed alterations in the Bragg's angle of the highest intensity peak as well as the other peaks of the treated sample. Also, the peak intensities and crystallite sizes corresponding to those peaks of the treated flutamide sample showed alterations ranging of $7.02 \%$ to $29.41 \%$ and $-9.17 \%$ to $17.86 \%$, respectively as compared to the untreated sample. Similarly, the average crystallite size of the Biofield Energy Treated flutamide sample was also increased by $2.84 \%$ compared to the control sample. Besides, the total weight loss of the Biofield Energy Treated sample was increased by $2.21 \%$ in TGA; whereas, the residue amount was significantly reduced by $64.16 \%$ as compared with the control sample. The DTG study showed that the $\mathrm{T}_{\text {max }}$ of the Biofield Energy Treated flutamide sample was significantly improved by $10.16 \%$ compared with the control sample. The Biofield Energy Treated sample revealed that the melting temperature and $\Delta \mathrm{H}_{\text {fusion }}$ were decreased by $0.57 \%$ and $9.37 \%$, respectively as compared to the untreated flutamide sample. Thus, the thermal analysis indicated the less thermal stability of the Biofield Energy Treated sample as compared to the control sample. Overall, the Trivedi Effect ${ }^{\circledR}$ Consciousness Energy Healing Treatment poses its impact on the flutamide sample, which might generate its new polymorphic form with altered crystallinity, particle size, and thermal stability. Such alterations in the Trivedi Effect ${ }^{\circledR}$ Treated flutamide may confirm its better designing in the form of nutraceutical and pharmaceutical formulations by providing better compactibility, flowability, and content uniformity, which might be used to offer better therapeutic response against prostate cancer, androgendependent skin and hair conditions including acne, seborrhea, hirsutism, and scalp hair loss, hyperandrogenism, as well useful for feminizing hormone therapy aimed at transgender women.

\section{Acknowledgements}

The authors are grateful to Central Leather Research Institute, SIPRA Lab. Ltd., Trivedi Science, Trivedi Global, Inc., Trivedi Testimonials, and Trivedi Master Wellness for their assistance and support during this work.

\section{References}

1. Sufrin G, Coffey DS (1976) Flutamide. Mechanism of action of a new nonsteroidal antiandrogen. Invest Urol 13(6): 429-434.

2. Labrie $F$ (1993) Mechanism of action and pure antiandrogenic properties of flutamide. Cancer 72(12): 3816-3827.

3. Marchetti B, Labrie F (1988) Characteristics of flutamide action on prostatic and testicular functions in the rat. J Steroid Biochem 29(6): 691-698.

4. Miranda A, Caraballo I, Millán M (2002) Stability study of flutamide in solid state and in aqueous solution. Drug Dev Ind Pharm 28(4): 413422.

5. Anjum S, Swan SK, Lambrecht LJ, Radwanski E, Cutler DL, et al. (1999) Pharmacokinetics of flutamide in patients with renal insufficiency. Br J Clin Pharmacol 47(1): 43-47.

6. Frass M, Strassl RP, Friehs H, Müllner M, Kundi M (2012) Use and acceptance of complementary and alternative medicine among the general population and medical personnel: A systematic review. Ochsner J 12(1): 45-56.

7. Barnes PM, Bloom B, Nahin RL (2008) Complementary and alternative medicine use among adults and children: United States, 2007. Natl Health Stat Report 12: 1-23. 
8. Rubik B (2002) The biofield hypothesis: Its biophysical basis and role in medicine. J Altern Complement Med 8(6): 703-717.

9. Koithan M (2009) Introducing complementary and alternative therapies. J Nurse Pract 5(1): 18-20.

10. Trivedi MK, Branton A, Trivedi D, Nayak G, Nykvist CD, et al. (2017) Evaluation of the Trivedi Effect ${ }^{\circledR}$ - Energy of Consciousness Energy Healing Treatment on the physical, spectral, and thermal properties of zinc chloride. American Journal of Life Sciences. 5(1): 11-20.

11. ]Trivedi MK, Patil S, Shettigar H, Bairwa K, Jana S (2015) Spectroscopic characterization of biofield treated metronidazole and tinidazole. Med chem 5(7): 340-344.

12. Trivedi MK, Branton A, Trivedi D, Shettigar H, Bairwa K, et al. (2015) Fourier transform infrared and ultraviolet-visible spectroscopic characterization of biofield treated salicylic acid and sparfloxacin. Nat Prod Chem Res 3: 186.

13. Trivedi MK, Branton A, Trivedi D, Nayak G, Mondal SC, et al. (2015) Morphological characterization, quality, yield and DNA fingerprinting of biofield energy treated alphonso mango (Mangiferaindica L.). Journal of Food and Nutrition Sciences 3: 245-250.

14. Trivedi MK, Branton A, Trivedi D, Nayak G, Mondal SC, et al. (2015) Evaluation of biochemical marker- Glutathione and DNA fingerprinting of biofield energy treated Oryza sativa. American Journal of Bio Science 3(6): 243-248.

15. Trivedi MK, Patil S, Shettigar H, Mondal SC, Jana S (2015) Evaluation of biofield modality on viral load of Hepatitis B and C viruses. J Antivir Antiretrovir 7: 083-088.

16. Trivedi MK, Patil S, Shettigar H, Mondal SC, Jana S (2015) An impact of biofield treatment: Antimycobacterial susceptibility potential using BACTEC 460/MGIT-TB System. Mycobact Dis 5: 189.

17. Trivedi MK, Branton A, Trivedi D, Nayak G, Charan S, et al. (2015) Phenotyping and 16S rDNA analysis after biofield treatment on Citrobacter braakii: A urinary pathogen. J Clin Med Genom 3: 129.

18. Trivedi MK, Tallapragada RM, Branton A, Trivedi D, Nayak G, et al (2015) The potential impact of biofield energy treatment on the physical and thermal properties of silver oxide powder. International Journal of Biomedical Science and Engineering 3(5): 62-68.

19. Trivedi MK, Tallapragada RM, Branton A, Trivedi D, Nayak G, et al. (2015) Analysis of physical, thermal, and structural properties of biofield energy treated molybdenum dioxide. International Journal of Materials Science and Applications 4(5): 354-359.

20. Trivedi MK, Branton A, Trivedi D, Nayak G, Mondal SC (2015) Effect of biofield treated energized water on the growth and health status in chicken (Gallus gallusdomesticus). Poult Fish WildlSci 3: 140.
21. Nayak G, Altekar N (2015) Effect of biofield treatment on plant growth and adaptation. J Environ Health Sci 1: 1-9.

22. Kinney JP, Trivedi MK, Branton A, Trivedi D, Nayak G, et al. (2017) Overall skin health potential of the biofield energy healing based herbomineral formulation using various skin parameters. American Journal of Life Sciences 5(2): 65-74.

23. Trivedi MK, Sethi KK, Panda P, Jana S (2017) A comprehensive physicochemical, thermal, and spectroscopic characterization of zinc (II) chloride using X-ray diffraction, particle size distribution, differential scanning calorimetry, thermogravimetric analysis/ differential thermogravimetric analysis, ultraviolet-visible, and Fourier transform-infrared spectroscopy. International Journal of Pharmaceutical Investigation 7(1): 33-40.

24. Trivedi MK, Sethi KK, Panda P, Jana S (2017) Physicochemical, thermal and spectroscopic characterization of sodium selenate using XRD, PSD, DSC, TGA/DTG, UV-vis, and FT-IR. Marmara Pharmaceutical Journal 21(2): 311-318.

25. Desktop X-ray Diffractometer “MiniFlex+”. The Rigaku Journal 14: 2936, 1997.

26. Zhang T, Paluch K, Scalabrino G, Frankish N, Healy AM, et al. (2015) Molecular structure studies of (1S,2S)-2-benzyl-2,3-dihydro-2(1Hinden-2-yl)-1H-inden-1-ol. J Mol Struct 1083: 286-299.

27. Langford JI, Wilson AJC (1978) Scherrer after sixty years: A survey and some new results in the determination of crystallite size. J Appl Cryst 11: 102-113.

28. Morin G, Briens L (2013) The Effect of Lubricants on Powder Flowability for harmaceutical Application. AAPS Pharm Sci Tech 14(3): 11581168 .

29. Hlinak AJ, Kuriyan K, Morris KR, Reklaitis GW, Basu PK (2006) Understanding critical material properties for solid dosage form design. J Pharm Innov 1(1): 12-17.

30. Inoue M, Hirasawa I (2013) The relationship between crystal morphology and XRD peak intensity on $\mathrm{CaSO}_{4} \cdot 2 \mathrm{H}_{2} \mathrm{O}$. J Crystal Growth 380: 169-175.

31. Brittain HG (2009) Polymorphism in pharmaceutical solids in Drugs and Pharmaceutical Sciences, volume 192, $2^{\text {nd }}$ Edn, Informa Healthcare USA, Inc, New York

32. Raza K, Kumar P, Ratan S, Malik R, Arora S (2014) Polymorphism: The phenomenon affecting the performance of drugs. SOJ Pharm Pharm Sci $1: 10$.

33. Zhao Z, Xie M, Li Y, Chen A, Li G, et al. (2015) Formation of curcumin nanoparticles via solution enhanced dispersion by supercritical $\mathrm{CO}_{2}$. Int J Nanomedicine 10: 3171-3181.

\section{Your next submission with Juniper Publishers will reach you the below assets}

- Quality Editorial service

- Swift Peer Review

- Reprints availability

- E-prints Service

- Manuscript Podcast for convenient understanding

- Global attainment for your research

- Manuscript accessibility in different formats

( Pdf, E-pub, Full Text, Audio)

- Unceasing customer service

Track the below URL for one-step submission

https://juniperpublishers.com/online-submission.php 